\title{
Metazoan fauna parasitizing Peckoltia braueri and Pterygoplichthys pardalis (Loricariidae) catfishes from the northeastern Brazilian Amazon
}

\author{
Adriele Carolina Franco CARDOSO ${ }^{1}$, Marcos Sidney Brito OLIVEIRA², Ligia Rigôr NEVES ${ }^{3}$, Marcos \\ TAVARES-DIAS ${ }^{1,3,4 *}$ \\ 1 Universidade Federal do Amapá (UNIFAP), Programa de Pós-Graduação em Biodiversidade Tropical (PPGBIO), Rod. Juscelino Kubitscheck 3296, Universidade, Macapá, Amapá, Brasil. \\ ${ }^{2}$ Universidade Federal do Oeste do Pará (UFOPA), Programa de Pós-Graduação em Recursos Aquáticos e Continentais Amazônicos (RACAM). Avenida Mendonça Furtado nº \\ 2946, Santarém, Pará, Brasil. \\ ${ }^{3}$ Universidade Federal do Amapá (UNIFAP), Programa de Pós-Graduação em Biodiversidade e Biotecnologia (PPGBIONORTE), Rod. Juscelino Kubitscheck 3296, Universidade, \\ Macapá, AP, Brasil. \\ ${ }^{4}$ Embrapa Amapá, Rod. Juscelino Kubitscheck 2600, km 5, CP 10, 68903-419 Macapá, Amapá, Brasil. \\ *Corresponding author: marcos.tavares@embrapa.br
}

\section{ABSTRACT}

This study investigated the metazoan parasite fauna in Peckoltia braueri and Pterygoplichthys pardalis from a tributary of the Amazon River system, in northern Brazil. In P. braueri, 630 parasites were collected, belonging to Unilatus unilatus, Nothogyrodactylus sp., Genarchella genarchella, Proteocephalus sp., Gorytocephalus elongorchis, Dolops longicauda and Hirudinea gen. sp., with a dominance of monogenean species. In $P$. pardalis, 120 parasites were collected, belonging to $U$. unilatus, Acanthostomum gnerii and Gorytocephalus elongorchis, and this acanthocephalan was the dominant species. In both hosts, the parasites presented clumped distribution, high prevalence, low abundance, low Shannon diversity, and low species richness, with a predominance of helminth species. In P. braueri, host length was positively correlated with parasite species richness and Shannon index. There was no difference in the body condition of parasitized and non-parasitized fishes in either host. This was the first report of these parasites in P. braueri and $P$. pardalis.

KEYWORDS: Digenea, diversity, helminths, parasites, freshwater fishes.

\section{Fauna de metazoários parasitando Peckoltia braueri e Pterygoplichthys pardalis (Loricariidae), bagres do nordeste da Amazônia brasileira}

\section{RESUMO}

Este estudo investigou a fauna de parasitos metazoários em Peckoltia braueri e Pterygoplichthys pardalis de um tributário do sistema do Rio Amazonas, no Amapá, norte do Brasil. Em P. braueri foram coletados 630 parasitos das espécies Unilatus unilatus, Nothogyrodactylus sp., Genarchella genarchella, Proteocephalus sp., Gorytocephalus elongorchis, Dolops longicauda e Hirudinea gen. sp., com dominância das espécies de monogenoideas. Em P. pardalis foram coletados 120 parasitos das espécies U. unilatus, Acanthostomum gnerii e Gorytocephalus elongorchis, sendo este acantocéfalo a espécie dominante. Os parasitos em ambos hospedeiros apresentaram dispersão agregada, elevada prevalência, baixa abundância, baixa diversidade de Shannon e baixa riqueza de espécies, com predominância de espécies de helmintos. Em P. braueri, o comprimento dos hospedeiros apresentou correlaçáo positiva com a riqueza de espécies de parasitos e o índice de Shannon. Não houve diferença entre a condição corporal de peixes parasitados e náo parasitados para os dois hospedeiros. Este foi o primeiro relato desses parasitos para $P$. braueri e P. pardalis.

PALAVRAS-CHAVE: Digenea, diversidade, helmintos, parasitos, peixes de água doce. 


\section{INTRODUCTION}

Loricariidae are endemic fishes of rivers, lakes and streams in the Neotropical region and represent the largest family of fish, with approximately 800 known species (25\% of Siluriformes diversity) (Armbruster 2011; Nelson 2016). Peckoltia braueri Eigenmann, 1912 (=Hemiancistrus braueri) and Pterygoplichthys pardalis Castelnau, 1855 (=Liposarcus pardalis), both objects of this study, are siluriforms distributed in the tropical regions of South America, mainly in the Amazon River system. Peckoltia braueri has a maximum length of $10.3 \mathrm{~cm}$, while $P$. pardalis can reach nearly $50 \mathrm{~cm}$ (Froese and Pauly 2016). Both fish species have sedentary behavior and inhabit the bottom of water bodies. They are omnivores and feed mainly on particulate organic matter (detritus), as well as filaments of single-celled algae and microorganisms associated with sediment, such as protozoans, fungi and bacteria (Fisch-Muller 2003; Mazzoni et al. 2010 a,b; Soares et al. 2011; Lujan et al. 2015; Froese and Pauly 2016).

Peckoltia braueri and P. pardalis have economic importance because, in addition to feeding riverside dwellers, they are used in aquariums (Baumgartner et al. 2012; Porto et al. 2012). When in environments with low levels of dissolved oxygen, these fishes use their extremely vascularized stomach as an accessory breathing organ. Due to this physiological adaptation, the food is not retained in the stomach and goes directly to the bowel (Santos et al. 2006; Froese and Pauly 2016). Despite the great diversity of Loricariidae, studies on the parasites fauna associated to these fishes are limited or scarce, depending on the species.

In general, fish can host a wide range of parasite taxonomic groups, which can affect behavior, metabolism, body condition, fertility and survival of the population (Barber $e t$ al. 2000; Lafferty 2008; Seppänen et al. 2009; Lacerda et al. 2013). Thus, parasitic infections may be one of many factors that may lead to a decrease in the quality and quantity of the fishery. The diversity and richness of parasites may vary among host species, and also as a function of age, size, diet composition, environment quality, and seasonality (Guidelli et al. 2006; Alarcos and Timi 2012; Neves et al. 2013; TavaresDias et al. 2014). Thus, the analysis of parasite communities and diversity parameters provides relevant information about host fish populations, expanding the knowledge of parasitehost-environment interactions. Pterygoplichtys pardalis is known to be parasitized by monogenean, digenean and acanthocephalan species (Thatcher and Varella 1981; Luque et al. 2011; Porto et al. 2012; Mendoza-Franco et al. 2010), but its parasitic fauna is not well known. The parasitic fauna of $P$. braueri has not been studied. Thus, the objective of this study was to investigate the parasite fauna of these fishes in a tributary of Amazon River system, in northern Brazil.

\section{MATERIALS AND METHODS}

\section{Study area and collection of fishes}

Igarapé Fortaleza basin, located in the area of the cities of Macapá and Santana, state of Amapá (northern Brazil), is a tributary of the Amazon River (Figure 1), formed by a main channel and an extensive floodplain area. The seasonal influence of high rainfall and the daily tides of the Amazon River, due to the proximity of its confluence with the Atlantic Ocean, originate an environmental variability that provides shelter and food for a great variety of fishes. The regional vegetation consists of floodplain forests and open herbaceous areas, mainly composed of several species of macrophytes (Thomaz et al. 2003; Tavares-Dias et al. 2014).

From November 2013 to November 2014, 39 specimens of $P$. braueri and 33 specimens of $P$. pardalis were captured in Igarapé Fortaleza River (Figure 1), using gill nets of different mesh sizes (15-50 mm between knots). Captured fishes were placed in containers with water and taken to the Laboratory of Aquatic Organisms Health of Embrapa Amapá, Macapá (Amapá) for a parasitological analysis.

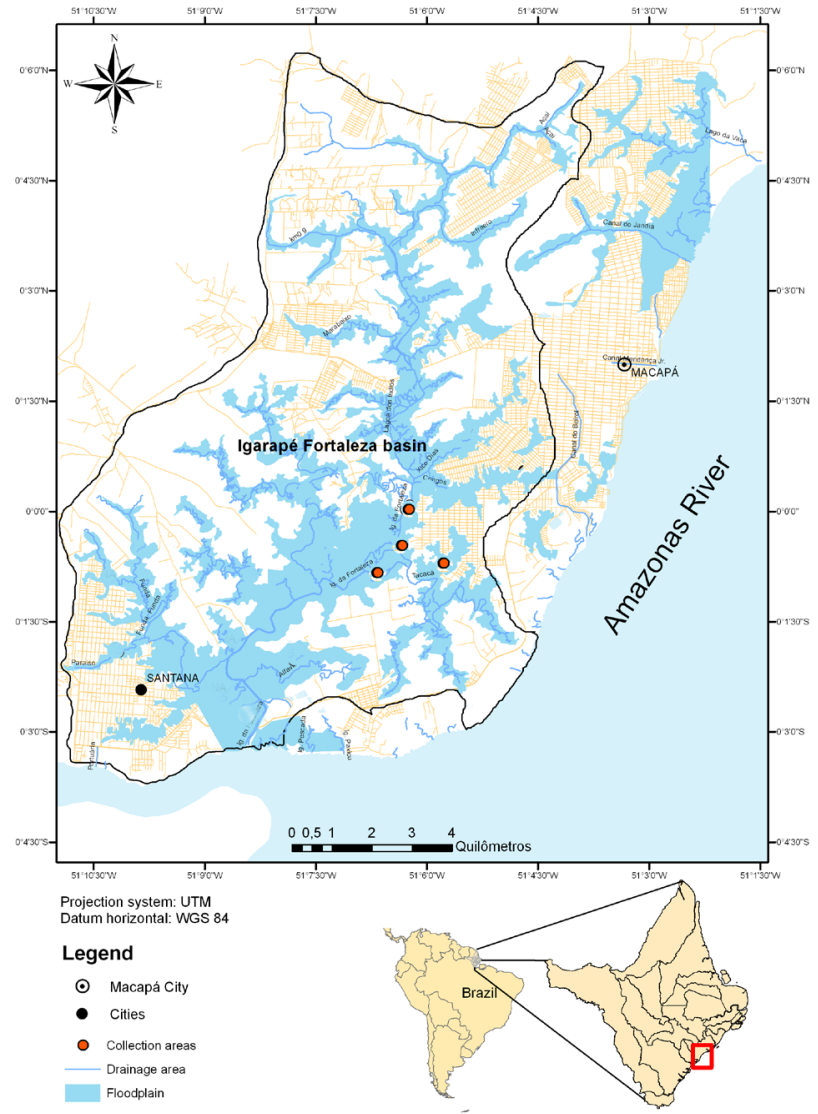

Figure 1. Collection sites of Peckoltia braueri and Pterygoplichthys pardalis in Igarapé Fortaleza basin, state of Amapá, northeastern Brazilian Amazon. This figure is in color in the electronic version. 


\section{Parasite analysis}

After measuring body weight (g) and total length, each fish was subject to necropsy for parasitological analysis. From each fish, mouth, opercula and gills were examined for the collection of ectoparasites and the gastrointestinal tract for the collection of endoparasites. Collection, fixation, preparation, counting, and staining of parasites for identification were according to Eiras et al. (2006). The ecological terms used in this study were according to Bush et al. (1997).

Shannon index $(H)$, evenness $(E)$, parasite species richness (Magurran, 2004) and dominance frequency (Rohde $e t$ al. 1995) were calculated to assess the component community of parasites using the Diversity software (Pisces Conservation Ltda, UK). Dispersion index (DI) and discrepancy index (D) were calculated using the Quantitative Parasitology 3.0 software to detect the distribution pattern of parasite infra-communities (Rózsa et al. 2000) for species with a prevalence higher than $10 \%$. For each infra-community, the DI significance was tested using the $d$ statistical test (Ludwig and Reynolds 1988).

Weight $(\mathrm{g})$ and total length $(\mathrm{cm})$ data of each host species were used to calculate the relative condition factor $(\mathrm{Kn})(\mathrm{Le}-$ Cren 1951) of parasitized and non-parasitized fishes, which was compared using Mann-Whitney test $(U)$. The Spearman's correlation coefficient $(r s)$ was used to determine possible correlations of host weight and length with parasite abundance, Shannon index, species richness and $H$ (Zar 2010).

\section{RESULTS}

From the 39 P. braueri examined, $48.8 \%$ were parasitized and 630 metazoans, i.e. monogeneans, acanthocephalan, digenean, cestode, argulid and leech species were collected, with a dominance of Unilatus unilatus Mizelle \& Kritsky, 1967 and Nothogyrodactylus Kritsky \& Boeger, 1991 (Monogenoidea), followed by Genarchella genarchella
Travassos, Artigas \& Pereira, 1928, while Dolops longicauda Heller, 1857 (Crustacea) and leeches were the less prevalent parasites. Larvae of Proteocephalus Weinland, 1958 (Cestoda) were also found (Table 1).

From the 33 P. pardalis examined, $60.6 \%$ were parasitized by monogeneans, acanthocephalans and digeneans, and 120 of these metazoan parasites were collected (Table 2). There was a dominance of Gorytocephalus elongorchis Thatcher, 1979 (Acanthocephala), followed by Acanthostomum gnerii Szidat, 1954 (Digenea). Peckoltia braueri and P. pardalis parasites presented clumped dispersion (Table 3). In both species, nonparasitized hosts were predominant (Figure 2).

For $P$. braueri, the Shannon index was $0.27 \pm 0.45$, evenness was $0.15 \pm 0.25$, and parasite species richness was $1.23 \pm 1.62$ parasites per host. Host length was positively and significantly correlated with parasite species richness $(r s$ $=0.662, \mathrm{p}=0.0001)$ and the Shannon index $(r s=0.578, \mathrm{p}=$ $0.0001)$. For $P$. pardalis, the Shannon index was $0.24 \pm 0.38$, equitability was $0.22 \pm 0.38$, and parasite species richness was $0.91 \pm 1.15$ parasite per host. The hosts length was not significantly correlated with parasite species richness ( $r s=$ -0.212, $\mathrm{p}=0.237)$ nor the Shannon index $(r s=-0.328, \mathrm{p}=$ 0.063). In P. braueri, the abundance of $G$. genarchella and $G$. elongorchis was positively and significantly correlated with the length and weight of hosts. In $P$. pardalis, no significant correlation of length and weight of hosts with parasite abundance was observed (Table 4).

The equation that describes the weight-length relation showed a negative allometric growth for both $P$. braneri ( $\mathrm{y}=$ $\left.0.1702 \mathrm{x}^{2.082}, \mathrm{r}^{2}=0.890\right)$ and $P$. pardalis $\left(\mathrm{y}=4.0497 \mathrm{x}^{1.281}, \mathrm{r}^{2}=\right.$ 0.317 ), which indicates a higher increase in body mass than in length in these hosts. The Kn in non-parasitized $(1.000 \pm 0.004)$ and parasitized $(1.000 \pm 0.005)$ P. braueri was similar $(U=143.0$, $\mathrm{p}=0.949)$, as it was in non-parasitized $(1.000 \pm 0.003)$ and parasitized $(1.000 \pm 0.001) P$. pardalis $(U=79.0, \mathrm{p}=0.060)$.

Table 1. Metazoan parasites in Peckoltia braueri from Igarapé Fortaleza basin, northeastern Brazilian Amazon. P: Prevalence, MI: Mean intensity, MA: Mean abundance, FD: Frequency of dominance, TNP: Total number of parasites, SI: Site of infection.

\begin{tabular}{lcccccc}
\hline Parasite species & $\mathrm{P}(\%)$ & $\mathrm{Ml}$ & $\mathrm{MA}$ & $\mathrm{FD}(\%)$ & TNP & SI \\
\hline Unilatus unilatus and Nothogyrodactylus sp. & 46.5 & 9.8 & $4.6 \pm 9.8$ & 0.31 & 196 & Gills \\
Genarchella genarchella & 9.3 & 6.25 & $0.6 \pm 0.2$ & 0.04 & 25 & Gills \\
Genarchella genarchella & 23.3 & 24.0 & $5.6 \pm 0.2$ & 0.38 & 240 & Intestine \\
Genarchella genarchella & 6.9 & 6.0 & $0.4 \pm 2.7$ & 0.03 & 18 & Stomach \\
Genarchella genarchella & 6.9 & 8.0 & $0.6 \pm 17.2$ & 0.04 & 24 & Abdominal cavity \\
Proteocephalus sp. (larvae) & 2.3 & 2.0 & $0.05 \pm 1.8$ & - & 2 & Stomach \\
Proteocephalus sp. (larvae) & 13.9 & 14.7 & $2.0 \pm 2.6$ & 0.14 & 88 & Intestine \\
Gorytocephalus elongorchis & 18.60 & 3.9 & $0.7 \pm 0.3$ & 0.05 & 31 & Intestine \\
Gorytocephalus elongorchis & 6.9 & 1.3 & $0.09 \pm 7.3$ & 0.01 & 4 & Abdominal cavity \\
Dolops longicauda & 2.3 & 1.0 & $0.02 \pm 1.9$ & - & 1 & Gills \\
Hirudinea gen. sp. & 2.3 & 1.0 & $0.02 \pm 0.4$ & - & 1 & Gills \\
\hline
\end{tabular}


Table 2. Metazoan parasites in Pterygoplichthys pardalis from Igarapé Fortaleza basin, northeastern Brazilian Amazon. P: Prevalence, MI: Mean intensity, MA: Mean abundance, FD: Frequency of dominance, TNP: Total number of parasites, SI: Site of infection.

\begin{tabular}{lcccccc}
\hline Parasite species & $\mathrm{P}(\%)$ & $\mathrm{Ml}$ & $\mathrm{MA}$ & $\mathrm{FD}(\%)$ & TNP & SI \\
\hline Unilatus unilatus & 15.2 & 3.4 & $0.52 \pm 1.7$ & 0.142 & 17 & Gills \\
Acanthostomum gnerii & 30.3 & 4.8 & $1.45 \pm 3.9$ & 0.400 & 48 & Intestine \\
\hline Acanthostomum gnerii & 6.1 & 1.0 & $0.06 \pm 0.2$ & 0.017 & 2 & Abdominal cavity \\
Acanthostomum gnerii & 3.0 & 4.0 & $0.12 \pm 0.7$ & 0.033 & 4 & Stomach \\
Gorytocephalus elongorchis & 45.5 & 3.3 & $1.48 \pm 2.2$ & 0.408 & 49 & Cavidade abdominal \\
\hline
\end{tabular}

Table 3. Dispersion Index (DI), Statistic- $d$ and discrepancy index (D) for parasite infracommunities of two Loricariidae species from Igarapé Fortaleza basin, northeastern Brazilian Amazon.

\begin{tabular}{lccc}
\hline Parasite species & DI & $d$ & D \\
\hline \multicolumn{1}{c}{ Peckoltia braueri } & & & \\
\hline Unilatus unilatus and Nothogyrodactylus sp. & 3.600 & 7.88 & 0.664 \\
\hline Genarchella genarchella (intestine) & 4.394 & 9.61 & 0.793 \\
\hline $\begin{array}{l}\text { Proteocephalus sp. (intestine) } \\
\text { Gorytocephalus elongorchis (intestine) }\end{array}$ & 3.171 & 6.86 & 0.872 \\
\hline \multicolumn{1}{c}{ Pterygoplichthys pardalis } & & & \\
\hline Unilatus unilatus & 2.491 & 5.10 & 0.833 \\
\hline Acanthostomum gnerii (intestine) & 2.547 & 4.83 & 0.858 \\
\hline Gorytocephalus elongorchis & 2.644 & 5.08 & 0.777 \\
\hline
\end{tabular}

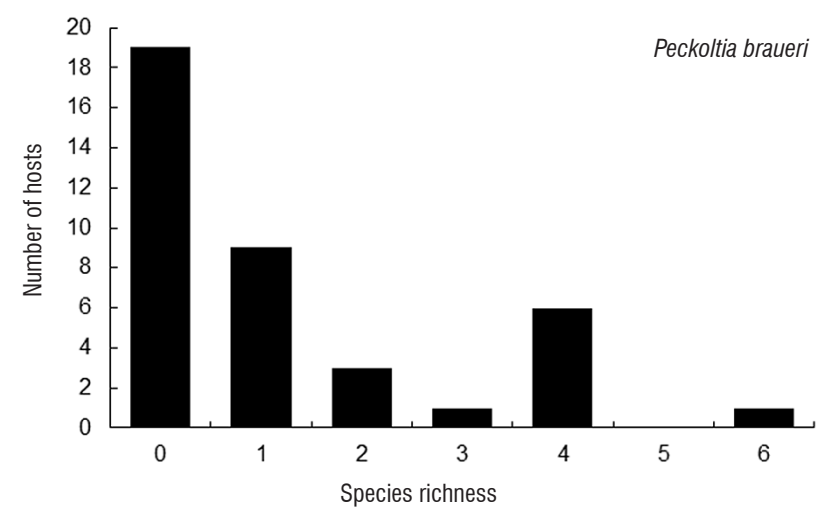

Table 4. Spearman correlation coefficient (rs) and the associated probability (p) of the abundance of parasite species with the total length and body weight for Loricariidae species from the Igarapé Fortaleza basin, northeastern Brazilian Amazon.

\begin{tabular}{lcccc}
\hline & \multicolumn{3}{c}{ Length } & \multicolumn{2}{c}{ Weight } \\
\cline { 2 - 6 } Parasite species & rs & $p$ & $r s$ & $p$ \\
\hline & Peckoltia braueri & & & \\
Unilatus unilatus and & 0.178 & 0.279 & 0.226 & 0.166 \\
Nothogyrodactylus sp. & 0.635 & $\mathbf{0 . 0 0 0 1}$ & 0.643 & $\mathbf{0 . 0 0 0 1}$ \\
Genarchella genarchella & 0.299 & 0.064 & 0.218 & 0.182 \\
Proteocephalus sp. & 0.573 & $\mathbf{0 . 0 0 0 1}$ & 0.476 & $\mathbf{0 . 0 0 2}$
\end{tabular}

\begin{tabular}{lcccc}
\multicolumn{5}{c}{ Pterygoplichthys pardalis } \\
Unilatus unilatus & 0.178 & 0.320 & 0.089 & 0.621 \\
Acanthostomum gnerii & 0.185 & 0.303 & -0.060 & 0.742 \\
Gorytocephalus elongorchis & 0.047 & 0.793 & -0.281 & 0.113 \\
\hline
\end{tabular}

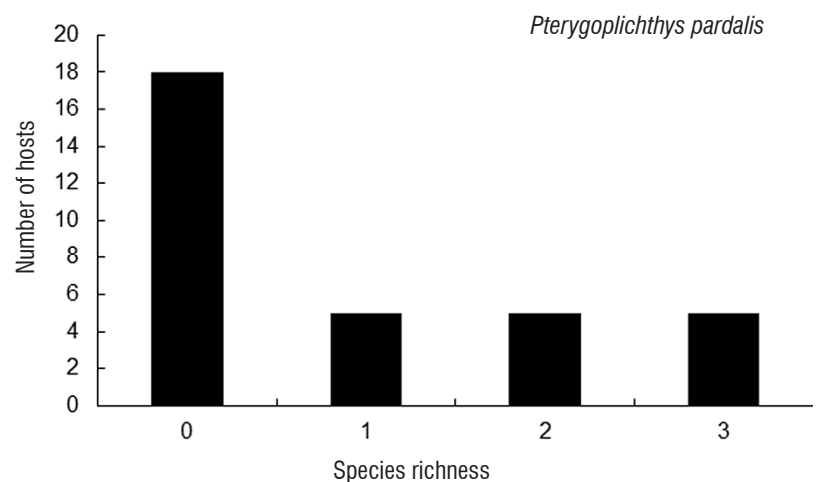

Figure 2. Species richness of parasites in two Loricariidae species from the Igarapé Fortaleza basin, northeastern Brazilian Amazon. 


\section{DISCUSSION}

In wild fish populations, the impact of parasitic infections can indicate a potential decrease in fishery production for consumption due to losses in quality and quantity, reduction in fish weight and body injuries that may lead to discarding the venture. The parasitic fauna of $P$. braueri and $P$. pardalis was composed of monogenean, acanthocephalan, digenean, cestode, crustacean and hirudinean species. However, Proteocephalus sp., D. longicauda, G. genarchella and hirudineans only occured in $P$. braueri, while $A$. gnerii parasitized only P. pardalis. Pterygoplichthys pardalis from different locations have been parasitized by Unilatus spp., Heteropriapulus spp., Megacoelium spinispecum Thatcher \& Varella, 1981, Austrodiplostomum compactum (Lutz, 1928) Dubois, 1970 and Gorytocephalus sp. (Thatcher and Varella 1981; Mendoza-Franco et al. 2010; Luque et al. 2011; Porto et al. 2012). When the same endoparasite is found in more than one host species in the same environment, it indicates the occurrence of new intermediate hosts in the habitat, in addition to the fact that different fish species share one or more food items (Marcogliese 2002).

In nature, the patterns among parasitic communities of host populations can be detected through quantitative and qualitative descriptors (Magurran 2004; Luque et al. 2013). In $P$. braueri and $P$. pardalis, Shannon diversity, equitability and species richness of parasites were low. In host fish populations, parasite diversity and richness depend directly on the population dynamics of birth, death, migration, age and diet of the host, presence of infective forms, environment quality, seasonality and geographical factors, among other biotic and abiotic factors (Luque et al. 2013; Hoshino and Tavares-Dias 2014; Tavares-Dias et al. 2014).

Monogenoidea is the most diverse taxa in fish from South America, with 835 species reported from hosts of different countries, most of them from freshwater habitats (Luque et al. 2016). Thirteen genera of monogeneans can be found parasitizing several species of Loricariidae, but Unilatus Mizelle \& Kritsky, 1967 and Trinigyrus Hanek, Molnar \& Fernando, 1974 (Dactylogyridae) are the most frequently encountered in these hosts (Cohen et al. 2013). In this study, P. braueri was parasitized by $U$. unilatus and Nothogyrodactylus sp., while P. pardalis was parasitized only by $U$. unilatus, but the level of infection was higher in $P$. braueri gills. These differences in parasitism levels are likely species-specific. This is the first record of $U$. unilatus in $P$. braueri and $P$. pardalis.

Genarchella genarchella is a widely distributed digenean in Characiformes and Siluriformes species from Brazil, Argentina and Uruguay (Scholz et al. 1995; Kohn et al. 2003; Franceschini et al. 2013). As this digenean species has mollusks and Cypriniformes species as intermediate hosts, and Characiformes and Siluriformes species are definitive hosts (Martorelli 1989;
Lefebvre and Poulin 2005). Peckoltia braueri in our study were infected by the ingestion of mollusks containing infective forms of this digenean. Acanthostomum gnerii, a digenean commonly found in the digestory tract of freshwater Siluriformes, has mollusk species as primary intermediate hosts, fishes of several species as secondary intermediate hosts and siluriform species as definitive hosts (Ostrowski-Nunez and Gil-Pertierra 1991; Gil-Pertierra and Ostrowski-Nunez 1995). In P. braueri, the levels of infection by $G$. genarchella were similar to those of $A$. gnerii in P. pardalis. However, the levels of infection by $A$. gnerii were higher than the ones reported for Rhamdia quelen Quoy and Gaimard, 1824 (Gil-Pertierra and Ostrowski-Nunez 1995). The abundance of $G$. genarchella increased with the size of $P$. braueri, indicating that larger individuals and, thus, older ones, host more parasites. Similar results were reported for Astronotus ocellatus Spix \& Agassiz, 1831 parasitized by Posthodiplostomum sp. (Neves et al. 2013). This is the first report of G. genarchella in $P$. braueri and of $A$. gnerii in $P$. pardalis.

Amazonian acanthocephalans are a group of parasitic worms that have attracted relatively little attention in comparison to other endohelminths. However, they are found in all classes of fish besides aquatic birds and mammals. Gorytocephalus elongorchis, described for the first time parasitizing Hipostomus carinatus Steindachner, 1881 (= Plecostomus carinatus) from Janauacá Lake, western Amazon region (Thatcher 1979), was found in P. pardalis and P. braueri, which are new hosts for this acanthocephalan. These results also expand the geographical distribution of $G$. elongorchis to the eastern Amazon region. The levels of infection by $G$. elongorchis in $P$. pardalis were high, while they were moderate in $P$. braueri. Furthermore, the abundance of $G$. elongorchis increased with the size of $P$. braueri, indicating that older individuals are more parasitized. Likewise, for other fish populations, the abundance or intensity of endohelminths increases with the age or size of the hosts (Rohde et al. 1995; Lacerda et al. 2013). This is the first report of $G$. elongorchis in $P$. pardalis and P. braueri.

Cestoda represents the third species-rich group of helminths in South America, with 460 species found in different countries (Luque et al. 2016). Proteocephalus species are the most frequent cestodes in Siluriformes from South America (Rego et al. 1999; Chambrier et al. 2006). Diaptomidae crustaceans and cyclopoid copepods are intermediate hosts for Proteocephalus species. Metacestodes or procercoids of this cestode develop in the body cavity of fishes, definitive or paratenic hosts, which are directly infected after consuming such infected crustaceans (Scholz 1999; Rego et al. 1999). Plerocercoids of Proteocephalus sp. were only found in $P$. braueri, and with low levels of infection, indicating that this fish may be a secondary intermediate host for this cestode species. 
This first report of $D$. longicauda in P. braneri showed infestation in only one host, similar to the findings in Metynnis lippincottianus Cope, 1870 (Hoshino and Tavares-Dias 2014), also from the same habitat of this study. This argulid presents a wide distribution in the Amazon River system (Tavares-Dias et al. 2015). Other ectoparasites with low levels of infestation in the gills were hirudinean species, which were also found in $P$. braueri gills. Therefore, the infections caused by $D$. longicauda and hirudineans in fish seem to be accidental.

\section{CONCLUSIONS}

This first study on $P$. braueri parasites shows that the parasitic fauna of $P$. braueri and $P$. pardalis is composed by a low diversity of metazoan species, predominantly by helminth species with high prevalence, low abundance and clumped distribution. This low abundance of parasites did not influence the body conditions of these two hosts. Finally, for P. braueri, host length explains $60 \%$ of the species richness and diversity of parasites. However, in $P$. pardalis, other factors that were not analyzed herein are responsible for parasite richness, low diversity and abundance.

\section{ACKNOWLEDGMENTS}

The authors thank the Conselho Nacional de Desenvolvimento Científico e Tecnológico (CNPq, Brazil) for the research fellowship (\#303013/2015-0) granted to Dr. M. Tavares-Dias.

\section{REFERENCES}

Alarcos, A.J.; Timi, J.T. 2012. Parasite communities in three sympatric flounder species (Pleuronectiformes: Paralichthyidae): similar ecological filters driving toward repeatable assemblages. Parasitology Research, 110: 2155-2166.

Armbruster, J.W. 2011. Global catfish biodiversity. American Fisheries Society Symposium, 77: 15-37.

Barber, I.; Hoare, D.; Krause, J. 2000. Effects of parasites on fish behaviour: a review and evolutionary perspective. Reviews in Fish Biology and Fisheries, 10: 131-165.

Baumgartner, G.; Pavanelli, C. S.; Baumgartner, D.; Bifi, A. G.; Debona, T.; Frana, V.A. 2012. Peixes do baixo Rio Iguaçu. EDUEM, Maringá, 200p.

Bush, A.O.; Lafferty, K.D.; Lotz, J.M.; Shostak, W. 1997. Parasitology meets ecology on its own terms: Margolis et al. Revisited. The Journal of Parasitology, 83: 575-583.

Chambrier, A.; Scholz, T.; Kuchta, R.; Posel, P.; Mortenthaler, M.; Guardia, C.C. 2006. Tapeworms (Cestoda: Proteocephalidea) of fishes from the Amazon River in Peru. Comparative Parasitology, 73: $111-120$.

Cohen, S.C.; Justo, M.C.; Kohn, A. 2013. South American Monogenoidea parasites of fishes, amphibians and reptiles. Oficina de Livros, Rio de Janeiro, 662p.
Eiras, J.C.; Takemoto, R.M.; Pavanelli, G.C. 2006. Métodos de estudo e técnicas laboratoriais em parasitologia de peixes. EDUEM, Maringá, 199p.

Fisch-Muller, S. 2003. Subfamily Ancistrinae (Armored catfishes). In: Reis, R.E.; Kullander, S. O.; Ferraris, C.J. Checklist of the freshwater fishes of South and Central America. EDIPUCRS, Porto Alegre, p.373-400.

Franceschini, L.; Zago, A.C.; Zocoller-Seno, M.C.; Veríssimo-Silveira, R.; Ninhaus-Silveira, A.; Silva, R.J. 2013. Endohelminths in Cichla piquiti (Perciformes, Cichlidae) from the Paraná River, São Paulo State, Brazil. Revista Brasileira de Parasitologia Veterinária, 22: 475-484.

Froese, R.; Pauly, D. 2016. FishBase. (www.fishbase.org). Accessed on $01 / 06 / 2016$.

Gil-Pertierra, A.; Ostrowski-Núñez, M. 1995. Ocurrencia estacional de Acanthostomum gnerii Szidat, 1954 (Acanthostomidae, Acanthostominae) y de dos espécies de Derogenidae, Halipegidae, parásitos del bagre sapo Rhamdia sapo Valenciennes, 1840 (Pisces, Pimelodidae) en Argentina. Revista Brasileira de Biologia, 55: 305-314.

Guidelli, G.M., Tavechio, W.L.; Takemoto, R.M.; Pavanelli, G.C. 2006. Fauna parasitária de Leporinus lacustris e Leporinus friderici (Characiformes, Anostomidae) da Planície de Inundação do alto Rio Paraná, Brasil. Acta Scientiarum. Biological Sciences, 28: 281-290.

Hoshino, M.D.F.G.; Tavares-Dias, M. 2014. Ecology of parasites of Metynnis lippincottianus (Characiformes: Serrasalmidae) from the eastern Amazon region, Macapá, State of Amapá, Brazil. Acta Scientiarum. Biological Sciences 36: 249-255.

Kohn, A.; Fernandes, B.M.M.; Baptista-Farias, M.F.D.; Cohen, S.C.; Fernandez, D.R.; Canzi, C. 2003. Helmintos parasitas dos peixes dos reservatórios de Itaipú e área de influência. Revista Brasileira de Medicina Veterinária, 25: 148-153.

Lacerda, A.C.F.; Takemoto, R.M.; Poulin, R.; Pavanelli, G.C. 2013. Parasites of the fish Cichla piquiti (Cichlidae) in native and invaded Brazilian basins: release not from the enemy, but from its effects. Parasitology Research, 112: 279-288.

Lafferty, K.D. 2008. Ecosystem consequences of fish parasites. Journal of Fish Biology, 73: 2083-2093.

Le-Cren, E.D. 1951. The length-weight relationship and seasonal cycle in gonadal weight and condition in the perch (Perca fluviatilis). Journal Animal of Ecology, 20: 201-219.

Lefebvre, F.; Poulin, R. 2005. Progenesis in digenean trematodes: a taxonomic and synthetic overview of species reproducing in their second intermediate hosts. Parasitology, 130: 587-605.

Ludwig, J.A.; Reynolds, J. F. 1988. Statistical ecology: a primer on methods and computing. Wiley-Interscience Pub, New York, 337p.

Lujan, N.K.; Armbruster, J.W.; Lovejoy, N.R.; Fernández, H. 2015. Multilocus molecular phylogeny of the suckermouth armored catfishes (Siluriformes: Loricariidae) with a focus on subfamily Hypostominae. Molecular Phylogenetics and Evolution, 82: 269-288.

Luque, J.L.; Aguiar, J.C.; Vieira, F.M.; Gibson, D.I.; Santos, C.P. 2011. Checklist of Nematoda associated with the fishes of Brazil. Zootaxa, 3082: 1-88. 
Luque, J.L.; Vieira, F.M., Takemoto, R.M.; Pavanelli, G.C.; Eiras, J.C. 2013. Checklist of Crustacea parasitizing fishes from Brazil. Checklist, 9: 1449-1470.

Luque, J.L.; Pereira, F.B.; Alves, P.V.; Oliva, M.E.; Timi, J.T. 2016. Helminth parasites of South American fishes: status and characterization as a model for studies of biodiversity. Journal of Helminthology, 8: 1-15.

Magurran, A. E. 2004. Measuring biological diversity. Blackwell Science, Oxford, UK, 256p.

Marcogliese, D.J. 2002. Food webs and the transmission of parasites to marine fish. Parasitology, 124: 83-99.

Martorelli, S.R. 1989. Estudios parasitologicos en biotopos lenticos de la Republica Argentina. V. Desarollo del ciclo biologico monoxeno de la metacercaria progenetica de Gernachella genarchella Travassos 1928 (Digenea: Hemiuridae) parasita de Littoridina parchappei (Mollusca: Hidrobiidae). Revista del Museo Argentino de Ciencias Naturales, 14: 109-117.

Mazzoni, R.; Rezende, C.F.; Manna, L.R. 2010a. Feeding ecology of Hypostomus punctatus Valenciennes, 1840 (Osteichthyes, Loricariidae) in a coastal stream from Southeast Brazil. Brazilian Journal of Biology, 70: 569-574.

Mazzoni, R.; Moraes, M.; Rezende C.F.; Miranda, J.C.B. 2010 b. Alimentação e padrôes ecomorfológicos das espécies de peixes de riacho do alto Rio Tocantins, Goiás, Brasil. Iheringia, Série Zoologia, 100: 162-168.

Mendoza-Franco, E.F.; Scholz, T.; Rozkosná, P. 2010. Tucunarella n. gen. and other dactylogyrids (Monogenoidea) from cichlid fish (Perciformes) from Peruvian Amazonia. The Journal of Parasitology, 96: 491-498.

Nelson, J.S. 2016. Fishes of the world. John Wiley and Sons, Inc. Hoboken, USA, 707p.

Neves, L.R.; Pereira, F.B.; Tavares-Dias, M.; Luque, J.L. 2013. Seasonal influence on the parasite fauna of a wild population of Astronotus ocellatus (Perciformes: Cichlidae) from the Brazilian Amazon. The Journal of Parasitology, 99: 718-721.

Ostrowski-Núñez, M.; Gil-Pertierra, A. 1991. The life history of Acanthostomum gnerii Szidat, 1954 (Trematoda: Acanthostomidae), from the catfish Rhamdia sapo in Argentina. Zoologischer Anzeiger, 277: 58-71.

Porto, D.B.; Vital, J.F.; Santos, A.K.S.; Morais, A.M.; Varella, A.M.B.; Malta, J.C.O. 2012. Metazoários parasitos de Pterygoplichthys pardalis (Castelnau, 1855) (Siluriformes: Loricariidae) da Amazônia central, Brasil. Revista Brasileira de Zoociências, 14: 35-40.

Rego, A.A.; Chubb, J.C.; Pavanelli, G.C. 1999. Cestodes in South America freshwater teleost fishes: keys to genera and brief description of species. Revista Brasileira de Zoologia, 16: 299-367.

Rohde, K.; Hayward, C.; Heap, M. 1995. Aspects of the ecology of metazoan ectoparasites of marine fishes. International Journal of Parasitology, 25: 945-970.
Rózsa, L.; Reiczigel, J.; Majoros, G. 2000. Quantifying parasites in samples of hosts. The Journal of Parasitology, 86: 228-232.

Santos, G.; Ferreira, E.; Zuanon, J. 2006. Peixes comerciais de Manaus. Ibama, Manaus, 141p.

Scholz, T.; Vargas-Vasquez, J.; Moravec, F.; Vivas-Rodriguez, C.; Mendoza-Franco, E. 1995. Metacercariae of trematodes of fish from cenotes (=sinkholes) of the Yucatan Península, México. Folia Parasitologica, 42: 173-192.

Scholz, T. 1999. Life cycles of species of Proteocephalus, parasites of fishes in the Palearctic region: a review. Journal of Helminthology, 73: 1-19.

Seppänen, E.; Kuukka, H.; Voutilainen, A.; Huuskonen, H.; Peuhkuri, N. 2009. Metabolic depression and spleen and liver enlargement in juvenile Arctic charr Salvelinus alpines exposed to chronic parasite infection. Journal of Fish Biology, 74: 553-561.

Soares, M.G.M.; Costa, E.L.; Siqueira-Souza, F.K.; Anjos, H.D.B.; Yamamoto, K.C.; Freitas, C.E. C. 2011. Peixes de lagos do médio Rio Solimóes. $2^{\text {nd }}$ revised ed., Instituto Piatam, Manaus, 172p.

Tavares-Dias, M.; Araújo, C.S.O.; Barros, M.S.; Viana, G.M. 2014. New hosts and distribution records of Braga patagonica, a parasite Cymothoidae of fishes from the Amazon. Brazilian Journal of Aquatic Science Technology, 18: 91-97.

Tavares-Dias, M.; Dias-Júnior, M.B.F.; Florentino, A.C.; Silva, L.M.A.; Cunha, A.C. 2015. Distribution pattern of crustacean ectoparasites of freshwater fish from Brazil. Revista Brasileira de Parasitologia Veterinária, 24: 136-147.

Thatcher, V.E. 1979. Uma nova espécie de Gorytocephalus Nickol e Thatcher, 1971 (Acanthocephala: Neoechinorhynchidae) do acari bodó (Pisces: Loricariidae) da Amazônia, Brasil. Acta Amazonica, 9: 199-202.

Thatcher, V.E.; Varella, A.B. 1981. Duas novas espécies de Megacoelium Szidat, 1954 (Trematoda: Haploporidae), parasitas estomacais de peixes da Amazônia Brasileira, com uma redefinição do gênero. Acta Amazonica, 11: 285-289.

Thomaz, D.O.; Costa-Neto, S.V.; Tostes, L.C.L. 2003. Inventário florístico das ressacas das bacias do Igarapé da Fortaleza e do Rio Curiaú. In: Costa-Neto, S.V.; Tostes, L.C. L.; Thomaz, D.O. Diagnóstico das ressacas do Estado do Amapá: bacias do Igarapé da Fortaleza e Rio Curiaú. CPAQ/IEPA e DGEO/SEMA, Macapá, p.1-22.

Zar, J.H. 2010. Biostatistical analysis. $5^{\text {th }}$ ed. Prentice Hall, New Jersey, 944p.

Received: 28/11/16

Accepted: 13/03/17 
